\section{Health care crisis in Gaza}

We, the 8 coauthors of this letter and the 59 Canadian physicians and scientists who have reviewed and endorsed it, are writing in response to 2 articles in the Mar. 17, 2009, issue of CMAJ: "Gaza's health care system crippled before - and after" by Christopher Mason and "On the ground in the Gaza Strip" by François Dumont.

The death of noncombatant civilians in Gaza, in Israel, or in any conflict is a tragedy. However, both articles failed to point out that the large majority of the casualties in Gaza were not civilians but combatants. We also found it regrettable that neither article addressed the role of Hamas, the government elected by the citizens of Gaza, in precipitating the crisis among its own people. The Hamas military launched rockets and fired on Israeli troops from within densely populated civilian areas. Schools were boobytrapped with bombs and mosques were used as weapon storehouses. Mason claims that "ambulance movement was severely restricted," yet he fails to indicate that Hamas used ambulances to transport its fighters. Incredibly, Hamas even used hospitals as military headquarters. Hamas fighters also created grenades out of medicine bottles and confiscated humanitarian aid directed for civilians, which contributed to the plight of its citizens.

Without the mention of these issues, the authors have not provided an accurate depiction of the events which led to the health care crisis in Gaza.

\section{Aaron D. Schimmer MD PhD}

Staff Physician and Scientist, Ontario

Cancer Institute, Princess Margaret

Hospital

David Malkin MD

Professor, Department of Pediatrics,

University of Toronto

Eldad Zackenhaus PhD

Senior Scientist, Toronto General

Research Institute

Allan Kagal MD

York Central Hospital

Amira Klip PhD

Senior Scientist, The Hospital for Sick Children

\section{Daniela Rotin PhD}

Senior Scientist, The Hospital for Sick

Children

Mark D. Minden MD PhD

Staff Physician and Senior Scientist,

Ontario Cancer Institute, Princess

Margaret Hospital

Jerome Teitel MD

St. Michael's Hospital, Toronto, Ont.

The authors' full affiliations and the names of the 59 physicians and scientists who endorsed this letter can be found online at www.cmaj.ca/cgi /eletters/180/6/610\#90551

Competing interests: None declared.

\section{REFERENCES}

1. Mason C. Gaza's health care system crippled before - and after. CMAJ 2009;180:608-9.

2. Dumont F. Dispatch from the medical front: on the ground in the Gaza Strip. CMAJ 2009;180:610.

DOI:10.1503/cmaj.1090038

\section{Correction}

In a review of the book After Shocks: The Poetry of Recovery for Life-shattering Events, ${ }^{1}$ commentary on a poem by Meir Wieseltier was inadvertently included as part of the poem itself. The section should read as follows:
Yet as she "draws with great flair Glasses and funny faces on all of them" she registers an innocent's protest against the forces that strip people of their liveliness, their humour, this distinct and colourful personalities, and ultimately their lives.

$C M A J$ regrets the error and apologizes for any inconvenience it may have caused.

\section{REFERENCE}

1. Downie G. Trauma relived. CMAJ 2009;180(5):544 DOI:10.1503/cmaj.090923

\section{Letters to the editor}

In submitting a letter, you automatically consent to have it appear online and/or in print. All letters accepted for print will be edited by CMAJ for space and style. Most references and multiple authors' names and full affiliations will appear online only. (The full version of any letter accepted for print will be posted on the website.) 